\title{
Correction: Pharmacogenomic associations of adverse drug reactions in asthma: systematic review and research prioritization
}

\author{
Charlotte King - Amanda McKenna - Niloufar Farzan - Susanne J. Vijverberg - Marc P. van der Schee - \\ Anke H. Maitland-van der Zee - Lambang Arianto - Hans Bisgaard (D) Klaus BØnnelykke • Vojko Berce • \\ Uros PotoČnik · Katja Repnik • Bruce Carleton • Denise Daley · Fook Tim Chew · Wen Chin Chiang · Yang Yie Sio • \\ Michelle M. Cloutier · Herman T. Den Dekker - Liesbeth Duijts • Johan C. de Jongste · F. Nicole Dijk • \\ Carlos Flores $($ Datalia Hernandez-Pacheco $\cdot$ Somnath Mukhopadhyay · Kaninika Basu $\cdot$ Kelan G. Tantisira • \\ Katia M. Verhamme - Juan C. Celedón 1 - Erick Forno - Glorisa Canino - Ben Francis $(\mathbb{D} \cdot$ Munir Pirmohamed • \\ lan Sinha $\cdot$ Daniel B. Hawcutt
}

Published online: 23 July 2020

(C) The Author(s) 2020. This article is published with open access

Correction to: The Pharmacogenomics Journal

$$
\text { https://doi.org/10.1038/s41397-019-0140-y }
$$

The original version of this article did not include Juan C. Celedón, Erick Forno and Glorisa Canino in the list of authors and incorrectly cited Gerard H. Koppelman, Maria Pino-Yanes and Steve Turner as authors. This has now been corrected in both the PDF and HTML versions of the article.

Open Access This article is licensed under a Creative Commons Attribution 4.0 International License, which permits use, sharing, adaptation, distribution and reproduction in any medium or format, as long as you give appropriate credit to the original author(s) and the source, provide a link to the Creative Commons license, and indicate if changes were made. The images or other third party material in this article are included in the article's Creative Commons license, unless indicated otherwise in a credit line to the material. If material is not included in the article's Creative Commons license and your intended use is not permitted by statutory regulation or exceeds the permitted use, you will need to obtain permission directly from the copyright holder. To view a copy of this license, visit http://creativecommons. org/licenses/by/4.0/. 